\section{Corruption and its Institutional Foundations: \\ The Experience of
South Korea \\ Tat Yan Kong}

IDS Bulletin Vol 27 No 21996

\section{Introduction}

On his inauguration in 1993 as the first civilian president of South Korea (hereinafter Korea) in over thirty years, Kim Young-sam pledge to eradicate corruption (through a so-called ' 100 days reform') and to accelerate the liberalization of the country's dirigiste economy. After a highly publicized and seemingly vigorous beginning, public confidence in the government was first rocked by a series of disasters resulting in heavy loss of life ${ }^{1}$ and which resulted in President Kim's governing Democratic Liberal Party (DLP) suffering a serious reverse in the local government elections of June 1995. Then in the autumn of 1995 came the confirmation $^{2}$ that former president Roh Tae-woo had amassed a secret political fund amounting to 500 billion won (approximately \$US US 650 million) during his presidency (1988-93). Moreover, veteran opposition leader, Kim Dae-jung, admitted to having received a modest \$US 2.5 million from Roh during the 1992 presidential election and attention is turning to the role of President Kim himself. If the disasters undermined public confidence in the government, then the slush fund scandal has cast doubt on the integrity of all civilian politicians in Korea, government and opposition alike. These happenings highlight, first, the continuing insulation of public officials from democratic accountability; second, the extent to which bureaucrats tolerated malpractices by the private sector for the sake of fast growth and financial gain; and, third, the saturation of the political system by secret money.

The Korean case, therefore, raises interesting questions about the relationship between corruption and economic and political change. First, in view of the firm evidence pointing to the longstanding prevalence of official corruption in Korean society, why did this not apparently impede the country's impressive economic growth? Second, if corruption did not hinder the macro-indicators of

\footnotetext{
The collapse of the Songsu Bridge in Seoul (21 October 1994) and an underground gas pipeline explosion caused by tunnelling in Taegu (28 April 1995) both did much damage to the government's image. The collapse of the upmarket Sampoong department store in Seoul on 29 June 1995 occurred just two days after the local elections.
}

${ }^{2}$ Korean newspapers had been reporting on speculation about this secret fund well before the actual disclosure. 
performance, what were the hidden costs of this phenomenon and how were these costs translated onto the political agenda? Third, if corruption is associated with the unaccountability of public officials and the existence of a cosy relationship between officialdom and its favoured producers, should we expect democratization and economic liberalization to remedy the problem or are there grounds to expect its persistence in spite of reform?

The answers to these issues converge on one point (and one which constitutes the thrust of the discussion below), namely that just as the Korean industrialization path defied neo-classical prescriptions in the 1960s and 1970s, liberal-inspired beliefs about the effects of democratization and economic liberalization are similarly misguided in the present Korean context. Rather, as the Japanese case also suggests, the institutional foundations of corruption (such as a close big business-government relationship, single party dominance, and interventionist bureaucracy) may well survive Korea's greater congruence with international trends towards democratization and liberalization.

Corruption takes many forms and definitions. Here, I define it as the following practices: the extraction and acceptance of payment from private entitities (be they individual citizens or businesses) by public officials; and the private misappropriation and abuse of public funds.

\section{Corruption and Authoritarian Industrialization, 1961-87}

From the inception of military-based rule in 1961 to the democratization of 1987 , Korea enjoyed rates of growth that were unprecedented in economic history. In contrast to the spasmodic growth spurts enjoyed by other LDCs (such as Brazil during the late 1960s), Korea's economic performance was sustained, resulting in a thoroughgoing tranformation

\section{${ }^{3}$ World Bank, The East Asian Miracle. Economic Growth and Public Policy (New York: Oxford University Press, 1993).}

${ }^{4}$ These points are embraced in the various classic works on Korean and East Asian industrialization. A. Amsden, Asia's Next Giant. South Korea and LateIndustrialization (New York: Oxford University Press, 1989) and R. Wade, Governing the Market (Princeton: Princeton University Press, 1990) discuss the of both industrial structure and popular welfare. A recent World Bank report on the East Asian region notes the combination of high growth and low inequality enjoyed by Korea.

The economic policies and socio-political framework underlying the success of the Korean authoritarian industrialization pattern have been widely commented upon: existence of a developmentalist bureaucracy modelled on the Japanese one; elimination of landordism (a barrier to industrial investment in many LDCs); government provision of cheap credit to the private sector in exchange for achieving export targets and other performance criteria (targeted subsidies); the mobilization of cheap productive labour; and the existence of an authoritarian political system that prevented the emergence of alternative economic strategies. ${ }^{4}$

From contemporary accounts and recent revelations, it is clear that corruption was a significant aspect of economic and political life during this period. The most obvious form of corruption consisted of political donations by business, first to President Park's DRP (Democratic Republican Party) and then to the DJP (Democratic Justice party) founded by his successor, President Chun. In exchange for favourable consideration (more of which below) or merely to be able to function unmolested (this applied especially to foreign companies), business had to contribute to the coffers of the ruling party. ${ }^{5}$ Not surprisingly, such donations greatly advantaged the ruling party within an institutional framework that already confined legal opposition to very narrow parameters. In exchange, business received a plethora of economic concessions: lax or non-enforcement of legal provisions concerning labour rights (often extending to violent physical intervention against workers) and public safety; deliberate oversight of irregularities in company accounts and holding patterns; subsidization of private investment from public funds

interventionist framework while the labour control mechanisms are explained in F. Deyo, Beneath the Miracle. Labour Repression in the East Asian Miracle (Berkeley: University of California Press, 1989).

${ }^{5}$ The relative weakness of business under Park is explained in Dal-joong Chang, Economic Control and Authoritarianism (Seoul: Sogang University Press, 1985) 
('policy loans'); the right to import scarce materials controlled under a restrictive trade regime; and government toleration of vast real estate acquisitions. Financial advantage accrued not only to the ruling party but to officials (and their relatives and associates) at all levels who were in a position to dispense favours to business. ${ }^{6}$

The exchange described above should have been a recipe for inefficiency, cronyism and mass social unrest. Yet the government-business relationship was the institutional foundation of the country's economic dynamism. How can we reconcile this apparent contradiction? Extensive government support (especially subsidized credit) only went to those businesses which fulfilled the government's ambitious export targets or which increased productive capacity in an officially designated priority sector. $^{7}$ Of course such firms kicked money back to the ruling party and other officials, but the point is that support from the government was contingent on demonstrated performance, a contrast with the government-business relationship that existed in the 1950 s and still pertaining in many LDCs today. There were other factors preventing corruption (at least in its unproductive or predatory form) from becoming the dominant aspect of Korean bureaucratic behaviour (the opportunity seemed greater than ever given the concentration of power after the 1961 coup). Apart from the training received under Japanese colonial rule, the developmentalist orientation of Korean bureaucracy could also be traced to historical circumstances: social unrest and civil war, rivalry with communist North Korea and US pressure for greater economic self-reliance. These factors impelled the Korean government to build legitimacy by achieving economic development and raising living standards.

While the above factors prevented corruption from stifling growth, there were also factors preventing it from eroding the social morale upon which long term development depended. Corruption is most socially polarizing and destabilizing when it occurs against a background of general impoverishment (by highlighting the advantages enjoyed by the rulers and their clients). By contrast, for Korea, growth coincided with general improvements in living standards, especially from the employment creation effect of labour-intensive industrialization in the 1960s. In spite of the existence of authoritarian anti-labour governments, the 1970s and 1980s saw sustained real wage increases for many groups of employees (especially the highly educated and those working in heavy industry). Moreover, the government also effected selective redistributive measures to moderate the social dislocations caused by its growth policies. For example, the New Village Movement of the early 1970s helped to reduce sectoral disparities by extending price supports to a rural sector hitherto squeezed for the benefit of industry. The Emergency Measures of August 1972 was a rescue package targeted at businesses (many of them small- and medium- sized) heavily indebted to the underground financial market. Anti-corruption campaigns that coincided with the leadership changes of 1961 and 1980, while serving as a convenient means of purging political opponents, also elicited public approval.

\section{The Hidden Costs and their Political Ramifications}

From the foregoing discussion, corruption was arguably 'functional' to Korean development during the authoritarian period in the sense that it cemented the government-business relationship. The government picked the winners and rewarded them for taking risks, while the winners ploughed some of their profits back into the political maintenance of the government and at the same time the economy grew. Inevitably, there was also a down side to this virtuous circle. The close governmentbusiness nexus (chongkyong yuchak or literally, 'political economic adhesion') also gave rise to a number of intractable social problems, many of which remain politically contentious to this day.

If corruption helped to consolidate the relationship between government and big business, the twin pillars of economic growth, it also imposed painful costs on those sections of society outside this charmed circle. Public disasters (sinking ferries, falling bridges, exploding gas pipelines, collapsing department stores) tell us a great deal about the contradictions of Korea development and the role

\footnotetext{
"One example was the scandal involving dealings in the underground financial market implicating President Chun's in-laws.
} 
of corruption within it. All the accidents pointed to the contractors' desire to cut corners, (whether by shoddy workmanship, using inferior material or neglecting safety) being tolerated by public officials for the sake of speeding up development. By contrast, Korean products overseas (be they buildings or manufactures) are competitively priced, increasingly sophisticated and obviously subject to strict quality control. This paradox illustrated the sacrifice of domestic popular interests in the promotion of export share: in exchange for export growth the government compensated producers by allowing monopolization of the domestic market (the sale of inferior products at inflated prices being one of its symptoms), guaranteed contracts on public projects (with some of the profits finding their way back to official party funds in the process) and the circumvention of already minimal regulations in areas such as public safety and labour rights.

Complementary to domestic monopolization was the provision of subsidized credit to proven exporters and those producers charged with developing the sectors designated strategic (usually the same business groups or chaebol). While being an effective instrument of industrial development, it also engendered opportunities for the misuse of public funds. So long as businesses fulfilled the aforementioned objectives, the government would turn a blind eye to their diversion of subsidies to non-productive purposes such as speculation in Seoul real estate (the demand for commercial and residential property there being insatiable) and the relending of funds on the underground financial market (itself a consequence of credit rationing). Apart from the opportunities and incentives for corruption arising from their servicing of business needs, senior government officials could also directly appropriate public funds for personal gain as was illustrated in the conviction in 1988 of former President Chun's brother for embezzlement from the Saemaul (New Village) Foundation. ${ }^{8}$

If the growth process enabled big business and government to derive major institutional and individual financial benefits, it must be remembered that such gains also occurred against a background of growing popular welfare. The reduction of absolute poverty and rising real wages throughout the 1970s and 1980 s suggests that the Korean growth model was far from exclusionary. But the mutual payoffs arising from the government-business relationship became increasingly sensitive politically and a focus of social discontent. How can we explain the emergence of corruption as a political issue during the 1980s?

The democratization of 1987 has often been explained in terms of authoritarianism becoming a victim of its own success. By satisfying basic needs and nurturing those sections of society (notably the middle class) that expected wider political participation, the authoritarian development model sowed the seeds of its own destruction." Democratization would probably not have occurred so quickly had there been no middle class support for the student protests in the summer of 1987 . In spite of their relatively privileged position compared to manual workers, Korea's middle classes harboured grievances against authoritarian rule, a number of which sprang from the abuses involved in the government-business nexus. Priority loans to big business made it difficult for small businessmen to borrow for expansion. Instead they had to borrow at exorbitant rates from the underground financial market, a sector in which the politically and economically powerful also dabbled. While real estate holdings might have compensated the chaebol for exporting at very tight profit margins, the spiralling of property prices put home ownership beyond the reach of not only the poor but most of the middle classes as well. Apart from the stifling effect of authoritarianism upon many professionals (especially in areas such as education and the media), the underside of the export platform touched the core of the middle classes' material existence.

The existence of conservative democratic alternatives (represented by Kim Young-sam and Kim Dae-jung) was another important factor facilitating the shifting of middle class opinion away from

\footnotetext{
${ }^{9}$ For example, see J. Cotton, 'From authoritarianism to democracy in South Korea', Political Studies 37 (1989).
}

\footnotetext{
'The corruption of 'Baby Chun' and Chun's wife are discussed in M. Clifford, Troubled Tiger. Businessmen, Bureaucrats and Generals in South Korea (Armonk: M.E. Sharpe, 1994). Clifford is impressed by the early promise of Kim Young-sSam's reforms.
} 
authoritarian rule. Notwithstanding the radical student factions (who also supported constitutional reform, albeit as a tactical measure), broad public opinion was for reform and not social revolution. The alternative to authoritarianism proffered by the Kims (a package that the erstwhile authoritarians themselves soon adopted) was an appealing one: individual freedom and the rooting out of the aforementioned abuses of power without sacrificing economic dynamism. Yet almost ten years has now elapsed since democratization and thoroughgoing reform has proven elusive, the issue to which we now turn.

\section{Democratization and Economic Liberalization}

Given that corruption is associated with the existence of a cosy relationship between public officials and their favoured producers, in theory, we should expect democratization and economic liberalization to erode the conditions on which corruption thrives. By opening up the political process, democratization subjects officials to the pressure of public scrutiny. It also facilitates the establishment of countervailing powers to the government and its clients. Economic liberalization leads to the separation of government and business. The motivation for collusion, the exchange of financial favours for domestic monopoly, disappears with the competition that liberalization brings. Such optimistic expectations, however, have not yet been borne out by the Korean experience of economic and political reform. After almost a decade since the fall of authoritarianism and despite repeated pronouncements about liberalization, corruption appears to remain deeply rooted in both the private and public sectors. How should we account for this pattern of behaviour and what are its implications?

Kim Young-sam promised clean government at the start of his presidency. He categorically stated that he would refuse any money offered to him by business. The anti-corruption emphasis appeared to have some substance when a number of senior military men and functionaries of the ruling DLP (Democratic Liberal Party) were dismissed from office in 1993. More significantly, after almost ten years of deliberation, a real names reform outlawing the holding of bank accounts under false names (a practice synonymous with corruption and tax evasion) was enacted in August 1993 and electoral laws placed strict limits on candidates' expenditures. While public disasters may be seen as legacies of the authoritarian past or even as the failure of enforcement at the local level, the persistent allegations of financial impropriety surrounding legislators of all parties cannot be so easily explained away. $^{10}$ On top of that, there is a lack of willingness to enforce regulations rigorously. ${ }^{11}$ For example, the rumour concerning the Roh political fund had been circulating for some time before formal action was taken $^{12}$ whilst in July 1994, the public prosecutor decided that former presidents Chun and Roh could not be punished for the misdemeanours committed during their rule although the government is under renewed pressure to recommence proceedings especially in the light of the corruption revelations. All this suggests that the foundations of money politics remain entrenched.

It can be argued that corruption persists because democratization and liberalization are in their infancy and that it will take a long period of reform for the decades of established malpractices to be reversed. Clearly political and economic reform still has some way to go before Korea measures up to the standards of a mature liberal-democracy. Democratization has not been consolidated and many aspects of authoritarian practice remain. In October 1994, the government reaffirmed that the National Security Law, which proscribes 'pro-North Korean activities', would be maintained. There are political prisoners from the 1950s who are only now being released from detention. More significant is the tougher line taken against the trades unions by the government after President Kim met with the leaders of big business. Independent labour

\footnotetext{
${ }^{10}$ For example, in October 1995, an opposition legislator, Un-tae Park, was arrested for taking bribes and influence peddling. In September that year, the opposition was offering to drop allegations about DLP legislators in exchange for the government dropping of charges against opposition legislators.
} 
activists have gone underground for fear of arrest and it is still impossible to form a union without official permission. Effective organized countervailing powers to the government-business nexus remain absent from Korean society. If Korea is a democracy in the strict procedural sense, it does not yet have the substance of a pluralistic society.

The intention of liberalizing the economy had been announced as far back as 1981 . The policy of liberalization was based on the perceived advantages of greater openness for enhancing efficiency in financial intermediation and industry. Through the 1980s, progress was slow as both the Chun and Roh governments pursued cautious programmes that minimized the dangers of liberalization such as the loss of domestic market share to foreign competitors, capital flight and the foreign take-over of key industries. The government continued to nurture financially certain strategic sectors (notably electronics and information technology) and to restrict foreign market access to sectors directly competitive with domestic producers (especially in automobiles and other consumer durables). Crucially instrumental to intervention was government control over the financial sector. The privatization of the leading commercial banks in 1982 did not diminish government influence since the banks were themselves heavily leveraged and reliant on the central bank. Tight regulations governing share dealing, direct investment and banking helped to limit foreign participation in Korean finance. Noting the sluggish pace of change under his predecessors, Kim Young-sam pledged to accelerate liberalization and promote the outwards movement of Korean investment, a process which he called 'internationalization' (segye hwa). On balance three years into the Kim administration, the overall picture continues to point to official caution. The much publicized international listing of the prominent public companies POSCO (steel) and KEPCO (power) in 1994 only served to highlight the extent to which foreign participation in the Korean financial system is still hedged by official controls.

The foregoing discussion links the persistence of corruption and other practices from the authoritar- ian industrialization era with incomplete political and economic reform. As an explanation, it is incomplete on two counts. First, it begs the question of why reform has not gone further. Second, it associates corruption with the capacity of the government to extract, whereas democratization and liberalization (however incomplete) accentuates the potential for corruption from the other side by enhancing the capacity of big business to bribe.

As we have seen, restrictions from the authoritarian era have survived the democratic transition and continue to block the emergence of a more accountable society in which corruption and other malpractices may be checked. ${ }^{13}$ Despite his stated concern at eradicating corruption, President Kim has been reluctant to further democratization and thus create the conditions whereby that goal may be realized. The reluctance of President Kim's civilian government to complete democratic reform is indicative of the government's order of priorities, namely, the maintenance of the conditions of conservative domination above all else. After all, the ruling DLP was formed from a merger of the governing party and two opposition parties in 1990 with the intention of establishing a hegemonic conservative party like the LDP (Liberal Democratic party) of Japan. As for the personnel turnover witnessed at the beginning of the Kim administration, they could be seen merely as leadership purges. Previous presidents (Park in 1961 and Chun in 1980) engaged in similar manoeuvring under the guise of fighting corruption, a view reinforced by the fact that members of President Kim's inner circle remained unscathed in spite of their alleged financial irregularities.

But explanation for the survival of the institutional foundations of corruption goes beyond elite intentions and requires discussion of the climate of public opinion upon which such machinations thrive. The first consideration is middle class opinion It was middle class dissatisfaction with Chun that lent critical support to the democratization movement in 1987. With its concern for continuing prosperity and worries about labour activism, a condition of that support was the existence of

\footnotetext{
${ }^{13}$ On the positive side, the power of the security agencies such as the army and the KCIA has been drastically pared back since 1987. See Young-chul Paik,
}

'Political reform and democratic consolidation in Korea', Korea and World Affairs Vol 28 No 4 (Winter 1994). 
credible moderate alternatives to authoritarianism. Not surprisingly, such a body of conservative democratic opinion has since gravitated to the DLP. Second, superimposed above all else is the regional dimension of Korean politics. Authoritarian industrialization greatly exacerbated the historical division between the Kyongsang (southeast) and Cholla (southwest) regions as successive presidents from the former (Park, Chun, Roh) skewed economic development in favour of their home region. Regional conflict persists and is kept alive as President Kim Young-sam is from Kyongsang while his principal opposition rival, Kim Dae-jung is from Cholla. Both leaders (together with Kim Jong-pil in his much smaller home province of Chungchong) have fanned regional sentiment for the sake of political advantage. Thirdly, the cold war with North Korea legitimized the doctrine of the security state whose legacy persists in spite of the gradual improvement of inter-Korean relations. These three factors underpin the conservative climate of public opinion and thwart further political democratization.

On the other hand, the partial democratization since 1987 has altered the nature of governmentbusiness relations. Whereas government dominance enabled it to extract finance from the business sector (for example, in donations to the ruling party), democratization has enhanced the independence of the latter but has not meant the diminution of corruption. This has led to a restructuring of the government-business nexus but has not affected the malpractices associated with that relationship. Business independence of the government is demonstrated by its disclosures of past donations to the ruling party and by its demands for accelerated liberalization, especially of the financial sector. ${ }^{14}$ Indeed, one conglomerate leader went as far as to challenge the DLP by launching his own political party. For their part, governments under both Roh and Kim stressed the importance of eradicating unproductive incomes and other manifestations of the underground economy. Yet despite these outward signs of conflict, one can also identify elements of close affinity between the two sides: government support for emerging industries; continued import restrictions; labour controls; and the business role in political funding, to give just a few examples. Moreover, rhetoric often disguises the lack of real change. For example, little headway has been made on the problem of real estate speculation amidst the serious housing shortage. Thus, the government-business nexus persists but in a modified form: business remains heavily reliant on government support, but democratization has widened its channels of influence over the government (with the formation of breakaway conservative parties being an extreme option) and enabled it to press its policy agenda, notably for accelerated liberalization (in order to establish the big business domination of the financial sector that the government seeks to avoid), more vigorously. ${ }^{15}$ Democratization has thus increased the channels by which business can use finance to affect the political process.

\section{Reflections on the Korean Pattern: Change and Resilience}

The wave of disasters and other scandals during the course of 1994-5 has once again ignited public anger over corruption and spotlighted the underside of the economic miracle, a world in which officials sacrifice the interests of ordinary citizens for the sake of achieving faster growth and personal gain. The institutional features and the seamier aspects of the Korean political economy bear many resemblances to those of Japan and the parallels caution against any temptation to predict far-reaching change in Korea.

That similarities between the Korean and Japanese political economies abound is not surprising given the latter's status as the former colonial power and the conscious Korean attempts at emulation since the early 1960s. The similar economic models of both countries (Japan also exercised great caution over the issue of liberalization) are sustained by a political process in which votes are secured by the dispensation of largesse, the ultimate provider of which is big business. The Japanese experience

\footnotetext{
${ }^{14}$ Jung-en Woo, Race to the Swift. State and Finance in Korean Industrialization (New York: Columbia University Press: 1991) chronicles the rise of business discontent with excessive intervention.
}

\footnotetext{
${ }^{15}$ That the partial liberalization of finance greatly strengthened the chaebol is discussed in A. Amsden and Yoon-dae Euh, 'Republic of Korea's financial reform: what are the lessons?', UNCTAD Discussion Paper 30 (UNCTAD: Geneva, April 1990).
} 
points to the successful maintenance of conservative rule in the face of public discontent over the results of government-business collusion. Electorally, the LDP survived the furore caused by the appalling environmental degradation of the 1960s (symbolized by the poisoning of a fishing village called Minimata) as well as the bribery scandals of the 1970 s and 1980s that removed three prime ministers. Notwithstanding the continuing over-representation of the pro-LDP areas and the party's vastly superior financial clout, 40 years of uninterrupted rule could not have been maintained without accommodating the all important public aspiration for growth. Similar conditions also buttress conservative rule in Korea where it is also grounded on a strong regional appeal to the most populous province. The Korean combination of authoritarian legacy and tense security situation makes the political spectrum much narrower: from the authoritarian remnants on the right of the DLP to Kim Dae-jung's cautious populism.
The effect of democratization and liberalization in Korea has been to strengthen one side of the government-business relationship (namely business) rather than to undermine the dominance of that nexus per se. Against this background, it is not surprising that corruption continues to thrive. The evidence from countries where liberalization is advanced is that it is more a formula for promoting efficiency in a very narrow sense than a check against corruption. By contrast, fighting corruption demands effective regulation, the necessary con-ditions of which are the existence of genuine countervailing institutional and societal powers. However, the very success of the Korean (and arguably, East Asian) capitalist strategy in fostering growth with mild redistributive measures is conducive to the pattern of arrested democratization discussed here. 